\title{
Research on College Students Humanistic Care of Ideological and Political Education
}

\author{
Qingsong $\mathrm{Li}^{1}$ \\ ${ }^{1}$ Chongqing University of Education, Chongqing, 400067 \\ 54892713@163.com
}

Keywords: Students' Ideological; Political; Humanistic Care

\begin{abstract}
In recent years, colleges and universities ideological and political humanistic care has get attention, but research is not rich enough to build their systems. In this paper, the ideological and political education Construction of humane care system. To strengthen the ideological and political education humanistic care, we must first establish the concept of people's freedom to develop comprehensive, content-rich humanistic care of ideological and political education on this basis, to change the traditional way of education from the principles, methods and ways to respect and strengthen ideological and political education team building who, enhance the effectiveness of ideological and political education.
\end{abstract}

\section{Introduction}

Humane Care is a loving and emotional modern educational philosophy and orientation, involving refers to the love of life, about humanity, the core is everything from people starting their own, attention to human values, emphasizing human dignity, advocated people-oriented, pay attention to the people's spiritual care of people, liberty life people's healthy growth, people's well-being and overall development as the ultimate care. Humanistic care of ideological and political education is an important theoretical and practical issues, strengthen ideological and political education of humanistic concern is the need of the times, is the need to improve the effectiveness of ideological and political education, the promotion of college students meet the needs of complex domestic and social environment.

By tracing the development trajectory of humane care of, we can come to understand Humanities: the "humane care refers to the realization of human comprehensive free development as the goal, to" people-oriented "as the core, from the people themselves starting to respect human needs, affirmation of human values, and constantly improve people's individuality and personality, to enhance the meaning of human existence acts as an important practice. Humanities includes human and cultural aspects, if the" person "is the starting point and destination, then the" text "is a necessary means care is an important way. Humanistic care is not equal care and humane care is different from the ordinary care that "humanism" features that in addition to the practical needs of people caring, more focused on the spirit of the people's concern and care, respect for life and the pursuit of the ideal and guidance. Humane care, not only to highlight the "people" dominant position, pay attention to human dignity, feelings, needs, personality and so on to meet and development, but also pay attention to the "culture" an important role in the "culture" of "man" to guide people to establish Ultimate. "? 'Humane care model is being carers really accept, is" you have a me "relationship rather than" I it "relationship, the care process is a combination of emotional and rational. Humanistic care with respect for human values and dignity, shaping people's independent personality, attention to people's individuality, attention to human survival and development, and explore the meaning of human existence as the main content. humanistic concern not only help to provide material on instilling human knowledge, but also the spiritual home of people Construction, psychological counseling, life ideal guide to explore the meaning of existence. 


\section{Value of Humanistic Care of Ideological and Political Education}

Tao Xingzhi once said, "Thousands of many religions teach, teach people to seek truth; Thousands Wanxue learn, learn to live," this sentence revealed the essential characteristics of education. The key to education is to promote the growth of the individual, to achieve inside and outside of unity. Ideological and political education focused on specific educational activities in the form of people's spiritual world, with value-oriented functions. Humanistic wisdom and human spirit is the ideological and political education itself should have meaning, so as to play its role in the human spirit in the Construction. Ideological and political education should fully reflect the value orientation of humanistic care, focusing on the existence and development of each individual student, concerned about the value of their lives meaning, and should pay more attention to students' spiritual beliefs, culture and moral personality. The ultimate mission is to promote ideological and political education full and free development of people, which is a concrete manifestation of Humanity. Ideological education is a kind of culture essence, molding, development of people, improve people's education activities to achieve humane care approach is not only ideological and political education, but the nature of internal ideological and political education determines the humanistic spirit should permeate care In all aspects of the ideological and political education among.

The theoretical basis of ideological and political education must be humane care of human nature and human nature theory of Marxism. Marx's theory of human nature that the nature of human nature, including human nature (natural property), social (social property) and subjective (mental attributes) three areas. Marxism believes human nature is the sum of all social relations. Ideological and political education has an important role in shaping human nature and the human dimension, focusing on humane care that will help shape its function. Human nature is expressed in the need for material, ideological and political education to respect and meet the material needs of normal people. Man is a social being, from birth to integrate into social life requires a process of socialization. Ideological and political education plays in the process of socialization an important role in human, a person is only mastered the mainstream values of society, internalized into their thinking, outside into their own actions, in order to integrate into society. Humanistic care of ideological and political education can strive to create a harmonious and stable social environment, and promote the process of human society. China is now in a period of social transformation, the huge social changes people's lives led to contemporary spiritual crisis, ideological and political education humanistic care can help people establish a correct world outlook, life outlook, values, and can provide great spiritual power for the individual. Humanistic care of ideological and political education can regulate conflicts in the production process, the construction of the human spiritual home, to strengthen people's own morality, promote people's words and deeds in line with social demands, enhance people's social. This is the ideological and political education in shaping perfect the humane care aspects of human nature.

\section{Ideological and Political Education to Achieve Humanistic Care Measures}

Change Traditional Way of Teaching. Promote dialogue on educational traditional ideological and political education teaching style is mainly to teach, mostly individual style, monologue, only to see the student textbook, listening to the teacher, take notes of these three simple activities. This teaching method is obedient education, whether students like it or not, teachers wishful thinking to instill students passively accept, can not actively play the students' enthusiasm, initiative, students pay attention to short duration, poor teaching. Change this way of teaching so that students come to participate in the teaching process. Dialogue is focused on teacher education and students from both sides of the equal dialogue, free exchange. They have to take the initiative, in good interaction, in which students learn, willing wherein teaching to achieve tangible results. Dialogue is a process of mutual understanding of teachers and students, we must learn to understand empathy, teachers should understand the students, it is necessary to take care of students. 
Strengthening Stealth Education and Focusing on Life Education. Famous educator Tao said, "life is education, namely school community." Ideological and political education of humanities education should be reflected in life, the use of stealth method of education, educator subtle influence of ethics, to cultivate their cultural literacy. The so-called implicit education is education through the creation of educational settings have a pattern, practice, cultural environment, the students thought the subtle influence behavior and infection of one obvious educational activities. Recessive education ideological and political education is education through the use of environmental and cultural campus, the teacher's own temperament and deeds were subtle influence of the educated and education so that everyone who receives an unconscious state, and often accept the ideological and political education, to purify the mind, strive, refreshing taste of spiritual purpose, it also effectively avoid rebellious emotions of students, to stimulate their active participation in awareness and improve the effectiveness of ideological and political education. School motto and regulations to be humane, to be able to guide and standardize the student's demeanor; the artificial environment of the school to be able to enhance students' awareness of environmental protection, for example, some schools green grass, hanging "do not track me, painlessly," the slogan, canteen there, "Who knows dishes on the menu, A Journey," the slogan, beside the water saying "my last tear you use the last drop of water" these vivid in virtually teaches students; school community activities to be able to develop students' team spirit and artistic taste, style of conversation educators give students set a good example for demonstration. These are reflected in the ideological and political education of people care, and virtually train the students in the humanities.

Pay Attention to the Emotional Mold Method. Emotional mold method is the use various factors in the context of education, to conduct probation educated and nurtured, educated culture subtle positive and healthy thoughts and feelings, and thus improve their ideological consciousness and moral level approach. Self-education is the basis of its main object of consciousness on, play the main role, according to the social and educators specifications and requirements, through self-selection, self-transformation, self-regulation and other processes, a purpose and a plan to transform and improve self quality of a highly self-conscious self-reflection activities. Practical exercises are organized, educated guide actively participate in various social practice, in the transformation of the objective world transform their subjective world, so as to continuously improve the method of ideological consciousness and cognitive ability. Materialist dialectics think things internal contradictions (i.e. internal) is the source and power of their own motion of things, is the fundamental reason for the development of things. External conflict (i.e. external) is the development of things, changing the second reason. Internal factors are the basis of change and external factors are changing conditions, external through internal causes. Emotional mold method is actually ideological and political education of external factors, external factors translate into student is inseparable from the concept of internal active participation of students, self-understanding, which requires students' self-education.

Explicit Education and Implicit Realization of A Unified Education. Dominant education refers to education and education influence is intuitive to determine the educational practice. The method is mainly dominant education indoctrination, the ideological and political education in education are the main form of explicit classroom education, seminars, lectures and so on. Education is a dominant advantage of timeliness and authority, the disadvantage is not conducive to play the initiative and creativity of students. Recessive education refers to education influence is indirect and uncertain educational practice. Ideological and political education in stealth education mainly through emotional mold, a model demonstration achieved. Culture and environment, the teachers own actions and behavior on campus all have subtle effects on students, unknowingly received education. Advantages implicit education is a wide range of lasting effect and the disadvantage is not clear educational purposes. In the ideological and political education should simultaneously focus on explicit education and implicit education. Dominant education can enable students to acquire knowledge of scientific theories, guide students to establish the correct ideals and firm convictions, students patriotism and social responsibility. Invisible education can make in 
the unconscious state students receive probation and nurtured, healthy students actively thinking, cultivate sentiments of students, aroused student emotional resonance. Invisible education dominant education provides guidance, stealth education makes explicit education more vivid and effective. Explicit teaching students better grasp theoretical knowledge, but invisible teaching student life, work. Infiltration of recessive Education explicit education requires educators to their love, their noble sentiments to infect students. Invisible education to strengthen the dominance of education, regardless of the construction of campus culture environment or educators demeanor should convey to students of a positive message to inspire students 'patriotic consciousness, national consciousness sense of innovation, realize students' personal and social values of unity.

\section{Conclusion}

The current era is an era of knowledge economy, the dominant position of people has become increasingly prominent, people-oriented harmonious society needs human care, humane education boom humanism is the current ideological and problem-prone, eager to humane care, thus strengthening the ideological and political education humanistic care has important theoretical and practical value. In theory, it can be able to substantiate the ideological and political education, ideological and political theory to consolidate basic education and reflects humane care of Marxist thought. In practice, it provides strong value orientation and spiritual motivation for college students, personality traits forge modern college students, ideological and political education to enhance the relevance, timeliness, promote the building of a harmonious campus.

\section{References}

[1] Shi Shuchen. The Ideological and Political Education of Individual Value of the New Development. Teaching and Research. 2007, (6).

[2] Zhao Jianping. Humanity in the Ideological and Political Education. Exploration (Philosophy and Social Science), 2007 (2).

[3] Ding Xiaowu. Socialist Study of the Ideological and Political Education of Marxism Humanity Foundation. Theory Guide (2008), (4).

[4] Liao Zhicheng. The Deviation and Correction under Marxist Perspective Enrollment Traditional Ideological and the Political Education. Ideological and Political Education Research. 2005 (5).

[5] Zhang Shujun, Liu Shihua. Moral Humanistic Spirit and Personality Development. Ideological Education Research. 2006 (1). 